i o j e s

www.iojes.net

\title{
Environmental Perception Scale: A Study of Reliability and Validity
}

\section{Research Article}

\section{Murset CAKMAK ${ }^{1}$}

${ }^{1}$ Mardin Artuklu University, Literature Faculty, Department of Educational Sciences, ORCID: 0000-0001-9472-8200

To cite this article: Cakmak, M. (2020). Environmental Perception Scale: A Study of Reliability and Validity, International Online Journal of Educational Sciences, 12(3), 281-303.

\section{ARTICLE INFO}

Article History:

Received: 27.05.2019

Available online:

23.07.2020

\section{ABSTRACT}

This study aims to develop a valid and reliable scale for the environmental perception of university students. The study was carried out in 2018, and a survey model was employed. With the help of the purposive sampling method, the study was conducted with 315 students attending different departments of universities. A draft scale of 56 Items related to environmental perception was formed. The data of the draft scale were created with aspects (such as metaphor/perception) about the concept of environment in Turkey, and the studies performed qualitatively were prepared in the light of expert views. The data obtained from scale implemented were subjected to total item correlation, exploratory and confirmatory factor analyses and reliability analyses. According to the results of analyses, it was seen that the scale was in the form of 32 items and 7 factors, and the variance rate explaining the whole scale was $60.859 \%$, and compliance index values were acceptable and in good agreement. A low and medium level relationship among factors a positive direction was obtained. Cronbach alfa internal consistency reliability coefficient was calculated as 0.930. All in all, it is understood that the environmental perception scale prepared in 5 point Likert scale was valid and reliable according to findings obtained.

(C) 2020 IOJES. All rights reserved

Keywords:

Environmental perception, scale, validity and reliability

\section{Introduction}

Living organisms and their non-living surroundings exist together in the same environment and are in interaction with each other without being separated (Cansaran \& Yıldırım, 2014; Özata Yücel \& Özkan, 2014; Yeşilyurt, Gül \& Demir, 2013; Jones \& Jones, 2002; Çakır, 2001; Odum, 1959). In this interaction, people who try to understand the world and themselves; attempt to make sense of their existence, the universe and everything around them, as far as they believe and know, and to bring a meaningful explanation to what is happening around them (Çopuroğlu, 2003). The perceptions and approaches of the human being, who is

${ }^{1}$ Corresponding author's address: Artuklu Üniversitesi

Telephone: +905070708046

e-mail: mursetcakmak@artuklu.edu.tr

DOI: https://doi.org/10.15345/iojes.2020.03.019 
inseparable with the environment he lives (Sadık, Çakan \& Artut, 2011; Gürbüz, Kışoğlu, Alaş \& Sülün; 2010), towards the close relationship with the environment he established in his childhood, is very important (Eryılmaz \& Kiran, 2017). A person scared of nature and needs to be protected against it as a result of his first experiences, has shown a tendency to take control of nature, to intervene and to change nature by dominating it with the culture and technology he has produced (Özerkmen, 2002; Hançerlioğlu, 1996; transferred by Baylan, 2009). Yet, these tendencies are natural and similar to the other living things, and the fact that humankind is in continual interaction with his environment due to the necessity of life. Nevertheless, he is less dependent on his environment and he can change the conditions, though partly, by his will (Çakır, 2001). The environment and nature are important habitat and source for human beings. Yet human beings have consumed these vital sources and caused environmental degradation (Erten, 2005; Ponmozhi \& Krishnakumari, 2017; Yücel et al., 2008). The consequences of this deteriorated balance have caused environmental problems affecting all living beings (Gürbüz \& Kişoğlu, 2017). Kormondy (1996) stated that these environmental problems are due to population growth, environmental pollution and increase in living standards and requirements (Çakır, 2001); however, Starr and Taggart (1997) expressed this as a result of logarithmical increase in today's human population, agricultural, medical and industrial revolutions. Schumaher (1995) pointed out that after World War II, the boom in industrial production gave rise to today's environmental problems, and Brown (1997) found that humans have made use of nature in such a way as to exceed the limits of the biological transport capacity, which has caused environmental problems. Theodore Roszak (1972) stated that it was the modern natural science which was responsible for environmental problems; and Skolimovkski (1967) expressed that the main reason for environmental problems was the basis of our scientific worldview and the perceptions of this world view (transferred by Kahyaoğlu \& Özgen, 2012).

On the other hand, the scientists searching for the reasons of the environmental pollution stated that, in fact, initially the minds and souls of people were polluted; afterwards, this pollution was reflected the social and biological environment, which led to the environmental pollution (Sülün, 2002). As can be seen, the sources of the environment and the perspectives to these problems are different. Although there are different points of view, it must not be forgotten that leaving a liveable environment for the next generations and all living beings is one of the most important duties for human beings (Uzun \& Sağlam, 2005).

Today, it is already known that natural resources have decreased with increasing population, and that environment al problems such as pollution challenges human life (Kaiser, Wolfing \& Fuhrer, 1999). People, who are aware of this fact, have started to protect living conditions of the environment, take precautions against the environmental problems and look for solutions (Sönmez \& Yerlikaya, 2017; Gürbüz \& Kışoğlu, 2011; Larijani \& Yeshodhara, 2008). Today, the authorities know that environmental problems can be solved with increased participation of the society and by undertaking responsibilities to be able to cope with them (Simon, 2015); therefore, they allocate a significant part of their budget for the solution of this issue. However, the easiest way to solve this problem is to bring up individuals, who will be able to find fundamental solutions to the environmental problems, produce services for the benefits of mankind, make use of them, and possess environmental information, conscientious and awareness (Erol \& Gezer, 2006; DiEnno \& Hilton, 2005; Uzun \& Sağlam, 2005). The aim of environmental awareness, as many scientists emphasize, is to create environmental information, positive attitudes to the environment and beneficial behaviours for the environment in an individual (Erten, 2005).

The necessary sensitivity should inevitably be set forth about environmental issues and information, attitudes and behaviours whereby individuals establish relationships with the environment for the protection of the environment should be known quantitatively and qualitatively. In recent years, it has been observed that researchers have prepared various data collection tools in this issue to gather relevant data. 
These tools are as follows: Environment Attitude Scale (Uzun, Gilbertson, Keles \& Ratinen, 2019; AlMenhali, Khalid \& Iyanna, 2018; Artvinli \& Demir, 2018; Saraç \& Kan, 2015; Ugulu, Şahin \& Başlar, 2013; Uzunöz, 2011; Metin, 2010; Milfont \& Duckitt, 2010; Uzun \& Sağlam, 2006; Maskan, Akkuş \& Demir, 2005), and Interest Scale for The Environment (Atli \& Uzun; 2016), and Consumer Environmental Awareness Perception Scale (Dikmenli \& Konca, 2016), Environmental Ethics Awareness And Attitude Scale (Nikhat \& Khan, 2017; Özer \& keleş, 2016), Environmental Knowledge Test (Ok \& Başlar, 2015), Environmental Literacy Scale (Szczytko, Stevenson, Peterson, Nietfeld \& Strnad, 2018; Lloyd-Strovas, Moseley \& Arsuffi, 2018; Sontay, Gökdere \& Usta, 2015; Özsevgeç, Artun \& Özsevgeç, 2010), Environmental Attitude and Awareness Scale (Soydan-Büyüktaşkapu \& Öztürk Samur, 2014), Motivation Scale for The Environment (Pelletier, Tuson, Green-Demers, Noels, \& Beaton, 1998), Environmental Awareness and Environmental Sensitivity Scale (Yeşilyurt, Gül and Demir, 2013), Environmental Behaviour Scale (Goldman, Yavetz, and Pe'er, 2006), and Attitude of Environmental Problems (Güven, 2013), Awareness Scale (Güven \& Aydoğdu, 2012), and Environmental Attitude and Information Scale (Leeming, Dwyera \& Bracken, 2010), Environmental Education Self-Efficacy Perception Scale (Özlü , Özer Keskin \& Gül, 2013; Özdemir, Aydın \& Vural, 2009), and Environmental Education Concepts Awareness Scale (Ötün, Artun, Temur \& Tozlu, 2017)

It was concluded that valid and reliable data collecting tools in the fields specified above were prepared with these studies conducted together with adults and candidate teachers of preschool, primary school, secondary school and high school. Although the environment seems clear and plain at first glance, it can be said that it has a complex structure when examined (Erol, 2005). Even in the literature presented above, this situation is seen in the diversity of study subjects on environmental issues. It is quite important how the environment, a concept which consists of different components, is perceptually thought by people, and how it is seen, and how it is felt, and how it is known and interpreted. Briefly, it needs to be known how people experience the environment. Every new perception requires the individual's previous experiences to take part in because perception is defined as the process to interpret various stimuli with the effect of previous experiences and to make them meaningful (MEB, 2014). In this study, a scale was designed by carrying out various syntheses and analyses of metamorphic research data having been performed on the environment so far. In other words, we tried to benefit from the experiences of the people about the environment. Therefore, this study aims to develop a valid and reliable scale to get an idea about university students' environmental perceptions.

\section{Method}

The survey method was used in this study. Survey research is one of the quantitative research methods which is not experimental and which is performed by using surveys and interview protocols (Christensen, Jhonson \& Turner, 2015). A survey method is a research approach aiming to describe a situation of past and present as it is (Karasar, 2005). In this study, thus, it was convenient to utilize the survey method since it aims to develop a valid and reliable scale to determine the perceptions of university students to the environment.

\section{Study Group}

The population of the study consisted of the students from Mardin Artuklu University, Ardahan University and Atatürk University in the 2017-2018 academic year. Demographic information of the participants in the study was summarized in Table 1.

Table 1. Demographic informations distribution of the participants

\begin{tabular}{llcc}
\hline Variables & & $\mathbf{f}$ & \% \\
\hline \multirow{3}{*}{ Gender } & Female & 201 & 63.8 \\
& Male & 114 & 36.2
\end{tabular}




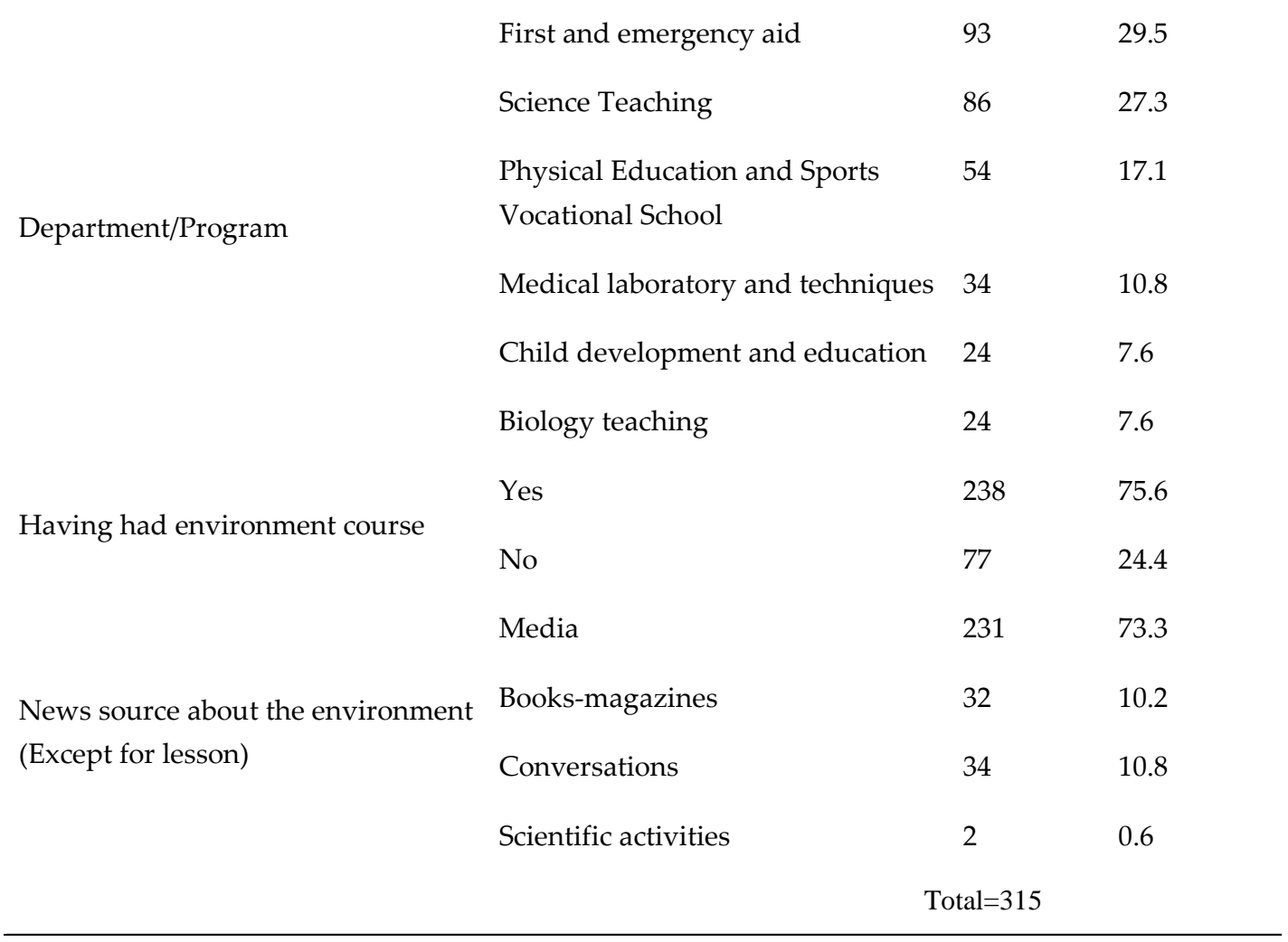

When Table 1, showing the demographic informations of the participants, was examined, it can be seen that $63.8 \%$ of the participants were women, while $36.2 \%$ were men; and that the number of the students attending to first and emergency aid, science teacher department, physical education and sport teaching department, medical laboratory and techniques, and child development and education and biology teaching programs/departments were $29.5 \%, 27.3 \%, 17.1 \%, 10.8 \%$, and $7.6 \%$, respectively. It was seen that while the rate of the students who have had a course on the environment was $75.6 \%$ and the rate of the students who have not had the course was $24.4 \%$. However, it was contemplated that the students who answered the question as "No" were of the programs/departments which have not taught this course yet. It can be seen that the rate of the students, who have declared that their information source to be out of class course, was $73.3 \%$, and books and magazines $10.2 \%$, and friends conversations $10.8 \%$, and scientific activities $0.6 \%$.

A purposive sampling was implemented in the study. Purposive sampling strategy, concerning the purpose of the study, provides the scientists with a deep searching facility since, in this method, rich cases are selected in terms of information (Büyüköztürk, Kılıç, Çakmak, Akgün, Karadeniz \& Demirel, 2015). While purposive sampling is used, the researchers determine the characteristics of the individuals making up the study population; and they reach the ones who match these features (Christiensen, Jhonson \& Turner, 2015). Great care was given to select the participants who were thought to contribute to research most richly and deeply for the environmental perception scale. Therefore, the related curriculums of the study group were examined. In the examination, it was observed that the study group had such courses as "environment and protection", "child and environment" and "environment science".

\section{Development Process of the Scale}

The stages that should be followed during the scale development process were as follows: Defining the problem/determining the objective, creating the scale items, referral to expert opinions, pre-application, validity and reliability stages (Erkuş, 2014; Tezbaşaran, 2008; Büyüköztürk, 2005). 


\section{Defining the problem/Determining the objective}

The objective of this study was to develop a valid and reliable environmental perception scale for university students.

\section{Creating the Scale Items}

In line with the aim of the study, the related literature was analyzed. In the literature, several studies carried out qualitatively about environment concept in Turkey (some metaphors/perceptions etc.) were examined. These studies were reached by writing key concepts such as environment, nature, environmental pollution, global warming in the National Research Centre of Higher Education, Tübitak Ulakbim, Google Academic search engine. As the result of research, the studies by the following authors were investigated and benefited: Arık \& Yılmaz (2017), Demir (2017), Doğan (2017), Karapınar \& Arıbaş (2017), Köseoğlu \& Mercan (2017), Akgün, Duruk \& Güngörmez (2016), Arslan \& Zengin (2016), Esentaş, Güzel, Özbey, Kılınç \& Çelebi (2016), Kahyaoğlu \& Kırıktaş (2016), Meral, Küçük \& Gedik (2016), Özmen \& Özdemir (2016), Yılmaz, Bedur, Uysal (2016), Çeliker \& Akar (2015), Kahyaoğlu (2015), Kaya (2014), Güven (2014), Ateş \& Karatepe (2013), Doğru \& Saraç (2013), Yalçınkaya (2013), Yazıcı (2013), Uyanık (2012), Aydın (2011), Aydın \& Coşkun (2011), Sadık, Çakan \& Artut (2011), Kaya, Coşkun \& Aydın (2010).

\section{Referral of expert opinion}

Before the expressions in the items pool were given the final draft scale form, the opinions of 2 biologists, 2 educational scientists, 2 science academics, who have had studies in the field, were referred about the draft scale. Initially, 47 items were prepared for the draft scale. Taking the related expert opinions into consideration, 9 new items were added to the scale; as a result, the scale took the shape of a draft scale with 56 items. The prepared draft scale was measured on 5-point Likert type scale (5: Totally Agree, 4: Disagree, 3 : Undecided, 2: I don't agree, 1: Never agree).

\section{Implementation of the application}

The necessary permissions were obtained from the universities where this study would be conducted in 2017-2018 academic year spring semi term so that the application could be performed. The 25-minute duration was given for the application.

\section{Results}

\section{Item Analysis}

Item analysis was developed to examine the relationship between the scores received from items taking place in the draft scale which was developed to determine environment perceptions of the university students and the total score of scale. For this, corrected item-total score correlations, one of the item analysis techniques were investigated. In general, it was proposed that item-total correlation should be 0.30 and that the higher items should remain on the scale since they differentiate the individuals very well (Büyüköztürk, 2010). Before exploratory factor analysis, it can be easily seen that except Item 38, all items were over 0.30. Item 38 was eliminated from the scale as it did not meet the criteria. 


\begin{tabular}{|c|c|c|c|c|c|c|c|}
\hline $\begin{array}{l}\stackrel{0}{Z} \\
\Xi \\
\Xi\end{array}$ & 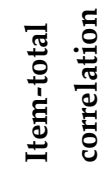 & $\begin{array}{l}\stackrel{0}{Z} \\
\Xi \\
\stackrel{\Xi}{\Xi}\end{array}$ & 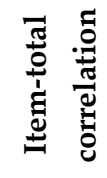 & 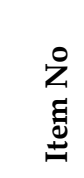 & 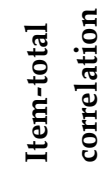 & $\begin{array}{l}\stackrel{0}{Z} \\
\Xi \\
\stackrel{\Xi}{\Xi}\end{array}$ & 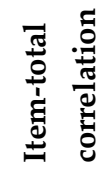 \\
\hline I-1 & 0.491 & I-15 & 0.442 & I-29 & 0.466 & I-43 & 0.583 \\
\hline I-2 & 0.489 & I-16 & 0.467 & I-30 & 0.589 & I-44 & 0.504 \\
\hline I-3 & 0.597 & I-17 & 0.641 & I-31 & 0.538 & I-45 & 0.597 \\
\hline I-4 & 0.605 & I-18 & 0.612 & I-32 & 0.381 & I-46 & 0.484 \\
\hline I-5 & 0.575 & I-19 & 0.650 & I-33 & 0.574 & I-47 & 0.541 \\
\hline I-6 & 0.499 & I-20 & 0.532 & I-34 & 0.513 & I-48 & 0.551 \\
\hline I-7 & 0.668 & I-21 & 0.629 & I-35 & 0.442 & I-49 & 0.504 \\
\hline I-8 & 0.602 & I-22 & 0.638 & I-36 & 0.363 & I-50 & 0.574 \\
\hline I-9 & 0.575 & I-23 & 0.599 & I-37 & 0.461 & I-51 & 0.399 \\
\hline I-10 & 0.542 & I-24 & 0.636 & I-38 & 0.198 & I-52 & 0.512 \\
\hline I-11 & 0.550 & I-25 & 0.653 & I-39 & 0.395 & I-53 & 0.486 \\
\hline I-12 & 0.551 & I-26 & 0.503 & $\mathrm{I}-40$ & 0.616 & I-54 & 0.346 \\
\hline I-13 & 0.538 & I-27 & 0.611 & I-41 & 0.583 & I-55 & 0.543 \\
\hline I-14 & 0.522 & I-28 & 0.431 & I-42 & 0.520 & I-56 & 0.391 \\
\hline
\end{tabular}

\section{Structural Validity}

In scale development and adaptation studies, the most preferred method to obtain data about the structural validity of a scale is factor analysis. Factor analysis is carried out as Exploratory and Confirmatory Factor Analysis (Seçer, 2017). Exploratory and Confirmatory Factor Analysis was performed to determine the structural validity of data obtained from the draft form of environment perception scale. For structural validity of environment perception scale, examining the concordance of data with factor analysis, obtaining the factors, turning the factors and titling the factors were carried out in four stages (Kalayc1, 2014).

\section{Exploratory Factor Analysis (EFA)}

Exploratory Factor Analysis is performed to find out under how many headings the items taking place in a scale tool can be collected and to determine what sort of relation there is between them (Seçer, 2017). While factor analysis is carried out on a scale, first of all, it is necessary to determine whether the data obtained are appropriate for factor analysis. For this purpose, it is essential that the size of sampling in which the scale is implemented be big enough. In factor analysis, it is generally accepted that sampling size should reach 300500 individuals; and the sampling size should reach 5 or 10 times of individuals of the number of items taking place in a scale (Seçer, 2017). To measure the sufficiency of the sampling used in the studies, Kaiser-MayerOlkin (KMO) coefficient, sampling sufficiency and Barlett test, is used (Büyüköztürk, 2005; Metin, 2015). The fact that KMO coefficient is bigger than 0.60 and that Barlett test turns out to be a meaningful show that data are appropriate for factor analysis (Büyüköztürk, 2010). 
To develop an environment perception scale, it was seen that the collected data were appropriate for factor analysis. The KMO coefficient of data was obtained as 0.901 , and Barlett test Chi-square value was found to be meaningful statistically $\left(X^{2}=4580.873 ; \mathrm{p}<0.01\right)$. For these resulting data, KMO coefficient can be interpreted to be excellent (Hutcheson \& Sofroniou, 1999; transferred by Seçer, 2017; Field, 2002, transferred by Metin, 2015; Leech, Barret Morgan, 2005; Şencan, 2005; Tavşancıl, 2005; transferred by Çokluk, Şekercioğlu \& Büyüköztürk, 2014).

In exploratory factor analysis, Principal Component Analysis technique was used in creating factor. In exploratory factor analysis, several criteria were generally taken into account in extracting items that do not measure the same structure. It was necessary to examine the height of the load on the factor in which the items were located. Factor load is the relationship between the factor in which the property is measured through an item (Büyüköztürk, 2010). Item factor load values should be at least 0.30 and above general acceptance (Seçer, 2017). However, some researchers suggest that this value should be 0.40 and 0.45 or higher to produce a stronger structure and scale (Seçer, 2017; Can, 2014; Büyüköztürk, 2010). For the environmental perception scale to have a strong structure, those whose item factor loadings were 0.45 and above were taken into account. It is stated that the substances should have high load value in one factor and low load values in the others. It was suggested that the difference between a factor with a high load value and a load of a second factor should be at least 0.10 . However, it is suggested to eliminate items with high load values in more than one factor (Çokluk, Şekercioğlu \& Büyüköztürk, 2014; Büyüköztürk, 2010). Factors with an eigenvalue greater than 1 or 1 as factor number criteria were considered as important factors (Büyüköztürk, 2010).

In the first exploratory factor analysis, it was found that the items were collected in 12 factors and the last 2 factors were found to contain at most 1 item. 23 items, which do not provide 0.45 item factor load value criterion, and which are considered to be comorbid items since they take place in more than one factor with less than 0.10, were eliminated and the number was decreased (I4, I10, I15, I19, I20, I21, I22, I24, I25, I26, I28, I32, I33, I37, I38, I39, I43, I48, I49, I50, I54, I55, I56). This process was repeated 4 times in total. Besides, I38 was removed from the scale through item-total correlation. Thus, a total of 24 items was eliminated.

When the factor loads were recalculated, it was seen the items were gathered under 7 factors. Then, Varimax orthogonal rotation technique (Büyüköztürk, 2010) was used so that the items that displayed high relation with one another in each factor could be brought together. With the help of Varimax rotational technique, it was seen that 32 items left in the scale had distributions under 7 factors.

Table 3. Rotated Component Matrix

\begin{tabular}{|c|c|c|c|c|c|c|c|c|c|c|c|c|c|}
\hline \multicolumn{2}{|c|}{ Factor1 } & \multicolumn{2}{|c|}{ Factor2 } & \multicolumn{2}{|c|}{ Factor3 } & \multicolumn{2}{|c|}{ Factor4 } & \multicolumn{2}{|c|}{ Factor5 } & \multicolumn{2}{|c|}{ Factor6 } & \multicolumn{2}{|c|}{ Factor7 } \\
\hline $\begin{array}{l}\stackrel{0}{Z} \\
\stackrel{\Xi}{ \pm}\end{array}$ & 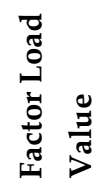 & 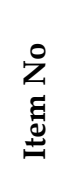 & 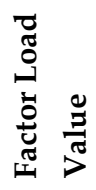 & $\begin{array}{l}\stackrel{0}{Z} \\
\stackrel{\Xi}{ \pm} \\
\stackrel{\Xi}{Z}\end{array}$ & 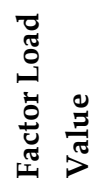 & $\begin{array}{l}\stackrel{0}{Z} \\
\text { Z } \\
\stackrel{ \pm}{ \pm}\end{array}$ & 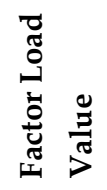 & 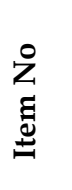 & 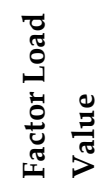 & $\begin{array}{l}\stackrel{0}{Z} \\
\stackrel{\Xi}{\Xi}\end{array}$ & 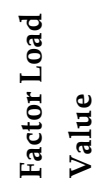 & 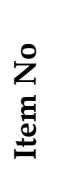 & 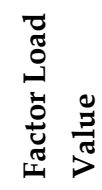 \\
\hline I-12 & 0.726 & I-2 & 0.729 & I-45 & 0.762 & I-30 & 0.717 & I-41 & 0.739 & I-36 & 0.814 & I-51 & 0.761 \\
\hline I-11 & 0.714 & I-1 & 0.707 & I-44 & 0.677 & I-29 & 0.705 & I-40 & 0.730 & I-35 & 0.775 & I-53 & 0.661 \\
\hline I-17 & 0.685 & I-3 & 0.669 & I-46 & 0.617 & I-31 & 0.683 & I-42 & 0.605 & I-34 & 0.652 & I-52 & 0.638 \\
\hline I-14 & 0.657 & I-8 & 0.649 & I-47 & 0.607 & I-27 & 0.503 & & & & & & \\
\hline I-18 & 0.654 & I-5 & 0.618 & & & & & & & & & & \\
\hline I-23 & 0.609 & I-7 & 0.577 & & & & & & & & & & \\
\hline
\end{tabular}




\begin{tabular}{|c|c|c|c|c|c|c|c|c|c|c|c|c|c|}
\hline \multicolumn{2}{|c|}{ Factor1 } & \multicolumn{2}{|c|}{ Factor2 } & \multicolumn{2}{|c|}{ Factor3 } & \multicolumn{2}{|c|}{ Factor4 } & \multicolumn{2}{|c|}{ Factor5 } & \multicolumn{2}{|c|}{ Factor6 } & \multicolumn{2}{|c|}{ Factor7 } \\
\hline 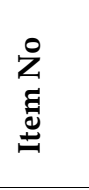 & 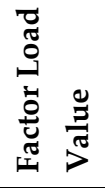 & $\begin{array}{l}\stackrel{0}{Z} \\
\text { Z } \\
\stackrel{\Xi}{*}\end{array}$ & 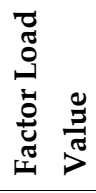 & 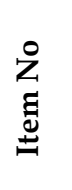 & 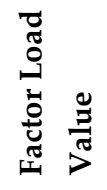 & $\begin{array}{l}\stackrel{0}{Z} \\
\text { Z } \\
\text { I }\end{array}$ & 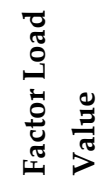 & $\begin{array}{l}\stackrel{0}{Z} \\
\text { Z } \\
\stackrel{\Xi}{\#}\end{array}$ & 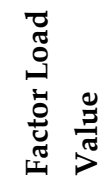 & $\begin{array}{l}\stackrel{0}{Z} \\
\Xi \\
\text { Z्ञ }\end{array}$ & 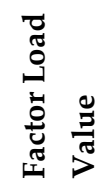 & $\begin{array}{l}\stackrel{0}{Z} \\
\text { Z } \\
\stackrel{ \pm}{ \pm}\end{array}$ & 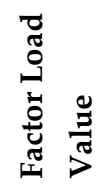 \\
\hline I-12 & 0.726 & I-2 & 0.729 & I-45 & 0.762 & I-30 & 0.717 & I-41 & 0.739 & I-36 & 0.814 & I-51 & 0.761 \\
\hline I-11 & 0.714 & I-1 & 0.707 & I-44 & 0.677 & I-29 & 0.705 & I-40 & 0.730 & I-35 & 0.775 & I-53 & 0.661 \\
\hline I-17 & 0.685 & I-3 & 0.669 & I-46 & 0.617 & I-31 & 0.683 & I-42 & 0.605 & I-34 & 0.652 & I-52 & 0.638 \\
\hline I-13 & 0.605 & I-9 & 0.500 & & & & & & & & & & \\
\hline I-16 & 0.604 & & & & & & & & & & & & \\
\hline
\end{tabular}

When the data obtained from the rotational component matrix were analysed, it was seen that the factor load values of the 8 items in factor 1 were between 0.726 and 0.604 , the items in factor 2 were between 7 items and the factor loadings were between 0.726 and 0.500 and factor load values between 0.762 and $0.607,4$ items in factor 4 between 0.717 and 0.503, 3 items in factor 5 were between 0.739 and 0.605 , and between 3.814 and 0.652 of 3 items in factor 6 , factor 3 items taking place in factor 7 load values were between 0.761 and 0.638 . It was observed that the item load values of all factors met the recommended 0.45 criteria.

Table 4. Variance Explanation Percentages of Factors

\begin{tabular}{lccc}
\hline Factors & Eigenvalues & $\begin{array}{c}\text { Variance } \\
\text { Percentage }\end{array}$ & $\begin{array}{c}\text { Total Variance } \\
\text { Percentage }\end{array}$ \\
\hline Factor1 & 10.211 & 13.374 & 13.374 \\
Factor 2 & 2.885 & 9.974 & 23.348 \\
Factor 3 & 1.731 & 9.111 & 32.458 \\
Factor 4 & 1.549 & 7.795 & 40.253 \\
Factor 5 & 1.428 & 7.068 & 47.321 \\
Factor 6 & 1.187 & 6.802 & 54.124 \\
Factor 7 & 1.092 & 6.735 & 60.859 \\
\hline
\end{tabular}

As a result of Varimax rotation, which was applied to the scale, in 7 factored structure, consisting of a total of 32 items whose eigenvalue were bigger than 1, it was explained that Factor 1 Total Variance was 13.374\%, Factor 2 Total Variance was 9.974\%, Factor 3 Total Variance was $9.111 \%$, Factor 4 Total Variance was $7.795 \%$, Factor 5 Total Variance was 7.068\%, Factor 6 Total Variance was $6.802 \%$ and Factor 7 Total Variance was $6.735 \%$. With the help of the obtained 7 factors, it was explained that total variance was $60.859 \%$. The fact that total variance is $30 \%$ and above that is explained is an acceptable result (Büyüköztürk, 2010).

\section{Reliability Study}

Cronbach Alpha coefficient was calculated to find out the reliability of the scale. 
Table 5. Cronbach Alpha Coefficient

\begin{tabular}{lcc}
\hline Factor & $\begin{array}{c}\text { Cronbach Alpha } \\
\text { Coefficient }\end{array}$ & Total Scale \\
\hline Factor 1 & 0.874 & \\
\hline Factor 2 & 0.867 & \\
Factor 3 & 0.775 & 0.930 \\
Factor 4 & 0.769 & \\
Factor 5 & 0.802 & \\
Factor 6 & 0.765 & \\
Factor 7 & 0.709 & \\
\hline
\end{tabular}

Cronbach Alpha Coefficient of developed environment perception scale was found 0.874 for Factor 1 , and 0.867 for Factor 2, and 0.775 for Factor 3, and 0.769 for Factor 4, and 0.802 for Factor 5, and 0.765 for Factor 6 and 0.709 for Factor 7; and for all the scale 0.930. It is accepted to be sufficient that the Cronbach Alpha coefficient is 0.70 and above this value (Chistiensen, Johnson \&Turner, 2015; Büyüköztürk, 2011; Tekindal, 2009).

In the developed environment perception scale, the fact that the Cronbach Alfa coefficients were above the recommended values showed that the scale had very high reliability.

Table 6. Correlation Coefficient Analysis Results between Factors

\begin{tabular}{|c|c|c|c|c|c|c|c|c|}
\hline & & F1 & F2 & F3 & F4 & F5 & F6 & F7 \\
\hline \multirow{3}{*}{ F1 } & $\mathrm{r}$ & 1 & & & & & & \\
\hline & & & & & & & & \\
\hline & $\mathrm{p}$ & & & & & & & \\
\hline \multirow{2}{*}{ F2 } & $\mathrm{r}$ & $0.681^{* *}$ & 1 & & & & & \\
\hline & p & 0.000 & & & & & & \\
\hline \multirow{2}{*}{ F3 } & $\mathrm{r}$ & $0.515^{* *}$ & $0.530^{* *}$ & 1 & & & & \\
\hline & $\mathrm{p}$ & 0.000 & 0.000 & & & & & \\
\hline \multirow{2}{*}{ F4 } & $\mathrm{r}$ & $0.544^{*}$ & $0.616^{* *}$ & $0.536^{*}$ & 1 & & & \\
\hline & $\mathrm{p}$ & 0.000 & 0.000 & 0.000 & & & & \\
\hline \multirow{2}{*}{ F5 } & $\mathrm{r}$ & $0.434^{*}$ & $0.553^{* *}$ & $0.527^{*}$ & $0.499^{*}$ & & & \\
\hline & $\mathrm{p}$ & 0.000 & 0.000 & 0.000 & 0.000 & & & \\
\hline \multirow{2}{*}{ F6 } & $\mathrm{r}$ & $0.260^{*}$ & $0.301^{* *}$ & $0.234^{*}$ & $0.344^{*}$ & 1 & & \\
\hline & $\mathrm{p}$ & 0.000 & 0.000 & 0.000 & 0.000 & & & \\
\hline \multirow{2}{*}{ F7 } & $\mathrm{r}$ & $0.335^{*}$ & $0.320^{* *}$ & $0.396^{*}$ & $0.377^{*}$ & $0.384^{* *}$ & 1 & 1 \\
\hline & $p$ & 0.000 & 0.000 & 0.000 & 0.000 & 0.000 & & \\
\hline
\end{tabular}

**. Correlation is significant at the 0.01 level (2-tailed). 
Pearson correlation coefficient was used to examine the relationship between the sub-dimensions of the perception scale. An absolute value of correlation coefficient between was interpreted 0.70-1.00 as a high-level relationship, between $0.69-0.30$ as a medium-level relationship, 0.29-0.00 as a low-level of relationship (Büyüköztürk, 2010). When these criteria were taken into consideration, while there was a weak relation in positive direction between F1 and F6 (r=0.260, p<0.05) and F3 and F6 (r=0.234; $<<0.05)$, between all other factors, it was observed that there was a medium level positive direction relation. This result can be interpreted such that the scale factors were positively related to each other.

\section{Naming the factors}

As a result of exploratory factor analysis and reliability analysis, 32 items collected in 7 factors were examined and named as follows: Factor 1: Perception of Environment Overview (PEO); factor 2: Environment Education perception (EEP); Factor 3: Environment Protection Perception (EPP); Factor 4: Environment Issue Perception (EIP); Factor 5: Environment Awareness Responsibility Perception (EARP); Factor 6: Environmental Problems Sensory Perception (EPSP); facto 7: Environment-Friendly Activities Perception (EFAP).

\section{First Level Confirmatory Factor Analysis}

Confirmatory factor analysis is based on testing a model or structure that was previously determined by exploratory factor analysis in scale development and adaptation process (Seçer, 2017). Confirmatory factor analysis is an advanced technique based on testing of theories about latent variables (Çokluk, Şekercioğlu \& Büyüköztürk, 2014). The first level confirmatory factor analysis was performed for the model consisting of 7 latent variables (PEO, EEP, EPP, EIP, EARP, EPSP, EFAP), and 32 observed variables, which were initially determined on the original scale for the confirmatory factor analysis of the environmental perception scale.

Table 7. Model Compliance Indexes

\begin{tabular}{|c|c|c|c|c|}
\hline $\begin{array}{l}\text { Compliance } \\
\text { Indexes }\end{array}$ & Excellent Compliance & $\begin{array}{l}\text { Acceptable } \\
\text { Compliance }\end{array}$ & Model & $\begin{array}{l}\text { Compliance } \\
\text { Interpretation }\end{array}$ \\
\hline RMSEA & $\begin{array}{c}\text { Between } 0.000 \\
\text { and }<0.50\end{array}$ & $\begin{array}{c}\text { Between }=0.50 \\
\text { and }=0.80\end{array}$ & 0.054 & Acceptable Fit \\
\hline RMR & Between 0.000 and $<0.50$ & $\begin{array}{c}\text { Between }=0.50 \\
\text { and }=0.80\end{array}$ & 0.055 & Acceptable Fit \\
\hline IFI & $=.95$ and over & $=.90$ and over & 0.97 & Acceptable Fit \\
\hline NNFI & $=.95$ and over & $=.90$ and over & 0.97 & Acceptable Fit \\
\hline NFI & $=.95$ and over & $=.90$ and over & 0.95 & Acceptable Fit \\
\hline CFI & $=.97$ and over & $=.95$ and over & 0.97 & Acceptable Fit \\
\hline GFI & $=.90$ and over & $=.85$ and over & 0.90 & Acceptable Fit \\
\hline AGFI & $=.90$ and over & $=.85$ and over & 0.86 & Acceptable Fit \\
\hline$\chi 2 / \mathrm{df}$ & $\begin{array}{l}\text { Should be smaller than } \\
\qquad \chi 2 / \mathrm{sd}=3\end{array}$ & & 1.309 & Acceptable Fit \\
\hline
\end{tabular}

(Schumacher and Lomax, 2004; transferred by Seçer, 2017)

As can be seen in Table 7, when the model compliance index values of the first level confirmatory factor analysis were examined, it was seen that the obtained values were $[302(\mathrm{sd}, \mathrm{N})=850.31 ; 443,315), \mathrm{X} 2 / \mathrm{sd}=$ $1.309, \mathrm{RMSEA}=0.054, \mathrm{~S}-\mathrm{RMR}=0.055, \mathrm{GFI}=0.90, \mathrm{AGFI}=0.86, \mathrm{NFI}=0.95, \mathrm{NNFI}=0.97, \mathrm{IFI}=0.97$ and $\mathrm{CFI}=$ 
0.97. According to this result, if the ratio of the chi-square to the degree of freedom is $=2 / \mathrm{df} / 2=$, it appears to be the perfect compliance (Tabachnick and Fidell, 2001; transferred by Çokluk, Şekercioğlu and Büyüköztürk, 2014). Moreover, it was found that IFI, NNFI and CFI values demonstrated excellent compliance, and RMSEA, RMR, NNFI, NFI, GFI and AGFI values displayed acceptable compliance.

Based on data, the model compliance of 32 items and 7-factor structure of the environmental perception scale was tested; and it was observed that the model was generally confirmed. The t-values of the path diagram of the first level confirmatory factor analysis were given in Figure 1.

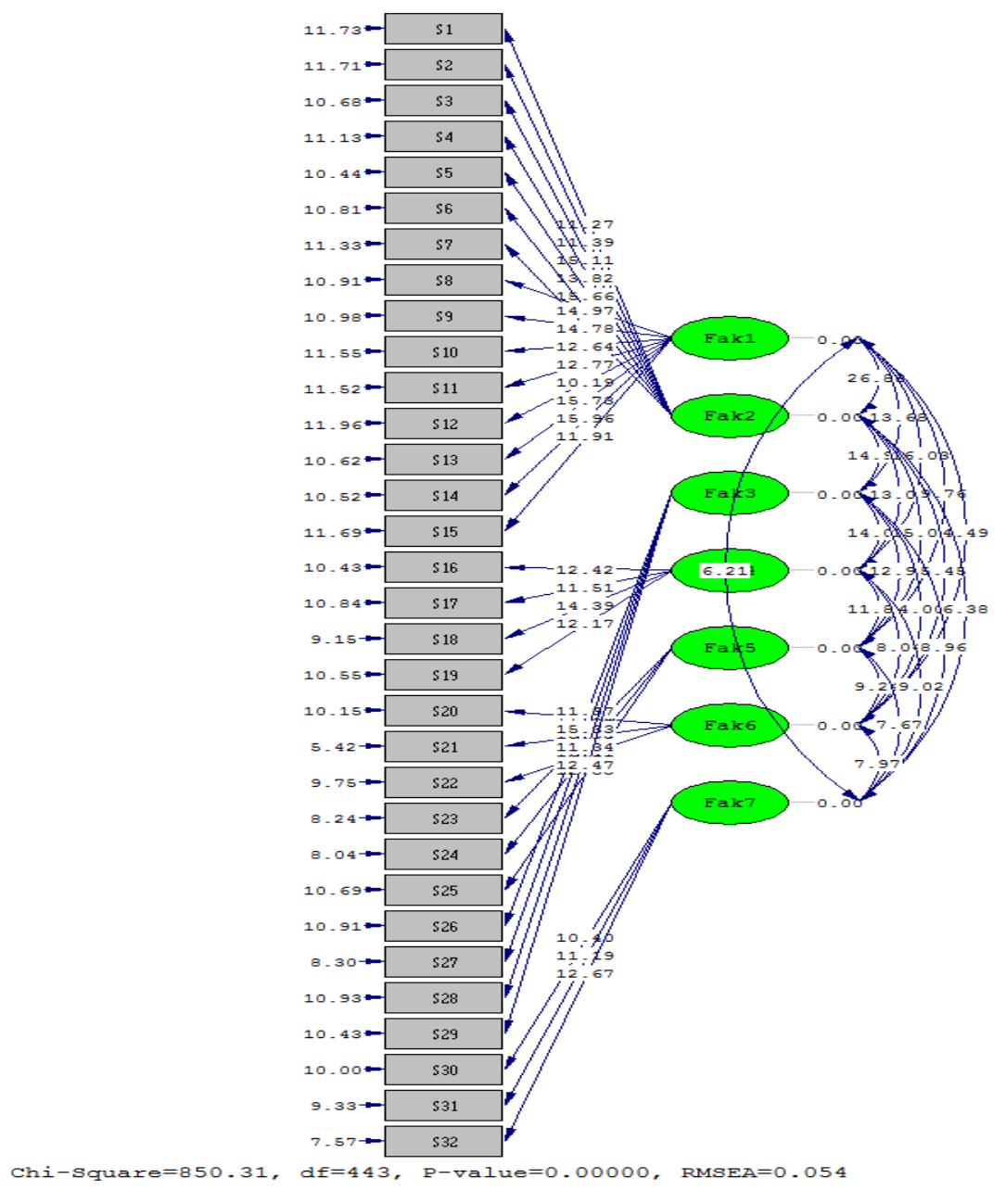

Figure 1. Environmental Perception Scale Path Diagram

\section{Results and Discussion}

This study was conducted to develop a valid and reliable scale for environmental perception. The literature was gone through in line with the aim of the study. In the literature review carried out, some metaphorical/perceptional studies and some qualitative studies carried out on environment concept in Turkey were examined. These studies were reached through the National Research Centre for Higher Education, Tübitak Ulakbim, Google Academic Search Engine. The item pool was created by examining related studies. The designed 47-item draft scale was submitted for expert opinion. Together with the feedbacks from the experts, the necessary arrangements were conducted; and 9 more items were added to the scale. The study was performed through survey method in 2018. While the sampling was determined, by examining some curricula of undergraduate and pre-graduate education, in the curriculum of any course in the field of science teaching, biology teaching, physical education and sports college, child development and education, first and 
emergency assistance, medical laboratories and techniques programs were selected for sample students. When the demographic characteristics of the selected sampling were examined, it is possible to say that the group consisted of people who know and recognize the environmental issues, are interested in them, and investigate them (Table: 1). After the necessary permissions were taken, the applied scale was subjected to the suggested analysis processes for scale developing studies. The scale items were analysed through item-total correlation, and an item was eliminated considering at least 0.3 item correlation criteria for each one (Table: 2).

In factor creation for the perception scale, Principal Component Analysis technique was used. In the analysis which was conducted, the fact that the value of the items in which the items is in the range of 0.45 and higher is considered to be a good scale to be selected. Besides, the suggestion that the difference between a factor with a high load value and a load of a second factor is at least 0.10 is also considered. To reveal the number of factors, the factors whose eigenvalues are 1 and bigger than 1 were taken into account as important factors.

The environmental perception scale was performed with the participation of 315 students. It is seen that this number is within the clearance which is between 300 and 500, the sampling size suggested for scale development studies in the literature. Furthermore, sampling adequacy analyses were carried out through Kaiser-Mayer-Olkin (KMO) coefficient and Barlett test. The KMO coefficient of the scale was obtained as 0.901, and it was observed that Barlett test Chi-square value was meaningful statistically $\left(X^{2}=4580.873 ; \mathrm{p}<0.01\right)$. These results can be interpreted as KMO coefficient being excellent.

In the first exploratory factor analysis, it was seen that the items were collected in 12 factors, and under the last 2 factors, there was only 1 factor at most. Factors were decreased by eliminating 23 factors which did not provide 0.45 criterion, 1 tem factor load value, and which were evaluated as comorbid items since they took place in more than one factor with less than 0.10 . This process was applied four times in total. Also, I38 was discarded from the scale with the help of item-total correlation. Hence, 24 items were eliminated.

As a result, it was observed that 32 items left with environment perception scale were gathered under 7 factors. Afterwards, to bring the items exhibiting high relations with one another in each factor together, Varimax Vertical Rotation Technique was used.

When the data obtained from rotated component matrix were examined, it was seen that 8 items, 7 items, 4 items, 4 items, 3 items, 3 items and 3 items were gathered in PEO, EEP, EPP, EIP, EARP, EPSP, and EFAP factors, respectively. Also, in all factors, it was seen that item load values had valued at least between 0.500 and 0.814 (Table: 3 ).

As a result of Varimax rotation applied to the scale, the total variance of PEO factor whose eigenvalue is bigger than 1 and with 7 factors is of 13.374\%, and EEP factor is of 9.974\%, and EPP factor is of 9.111\%, and EIP factor is of $7.795 \%$, and EARP factor is of $7.068 \%$, and EPSP factor is of $6.802 \%$, and EFAP factor is of $6.735 \%$. The total variance is explained to be $60.859 \%$ with the help of 7 factors.

It was found that the Cronbach Alpha Coefficient of the developed environment perception scale changed between 0.709 and 0.930. The fact that the Cronbach Alpha Coefficient had a value over 0.70 with all suggested factors shows that the perception scale is a reliable one (Table: 5).

When Pearson Correlation Coefficient for environment perception is examined, a weak relationship in a positive direction was found with PEO, EPSP, EPP and EFAP factors, while there emerged a medium level relation in positive direction between all other factors. This result can be interpreted that the factors in the scale have relations in a positive direction between each other (Table: 6).

Besides, for confirmatory factor analysis, primary level confirmatory factor analysis was carried out for the model composed of 7 hidden variables (PEO, EEP, EPP, EIP, EARP, EPSP, and EFAP) and 32 observable 
variables which were initially determined in original scale in the study. When compliance index values about primary confirmatory factor analysis were examined, it was found out that the obtained compliance index values were $[\chi 2(\mathrm{sd}, \mathrm{N})=850.31 ; 443.315), \chi 2 / \mathrm{sd}=1.309$, RMSEA=0.054, RMR=0.055, GFI=0.90, AGFI=0.86, $\mathrm{NFI}=0.95, \mathrm{NNFI}=0.97, \mathrm{IFI}=0.97$ and $\mathrm{CFI}=0.97$. According to this result, it was found that $(\chi 2 / \mathrm{df}), \mathrm{IFI}, \mathrm{NNFI}$ and CFI, the ratio of Chi-square value to the degree of freedom showed excellent compliance; and RMSEA, RMR, NNFI, NFI, GFI and AGFI values showed acceptable compliance (Table:7). Consequently, it is seen that the environment perception scale is a valid and reliable scale to be used in revealing the perceptions of university students about the environment. This scale, with various adaptations, can be utilized for other individuals in formal or informal processes out of university by considering their characteristics. 


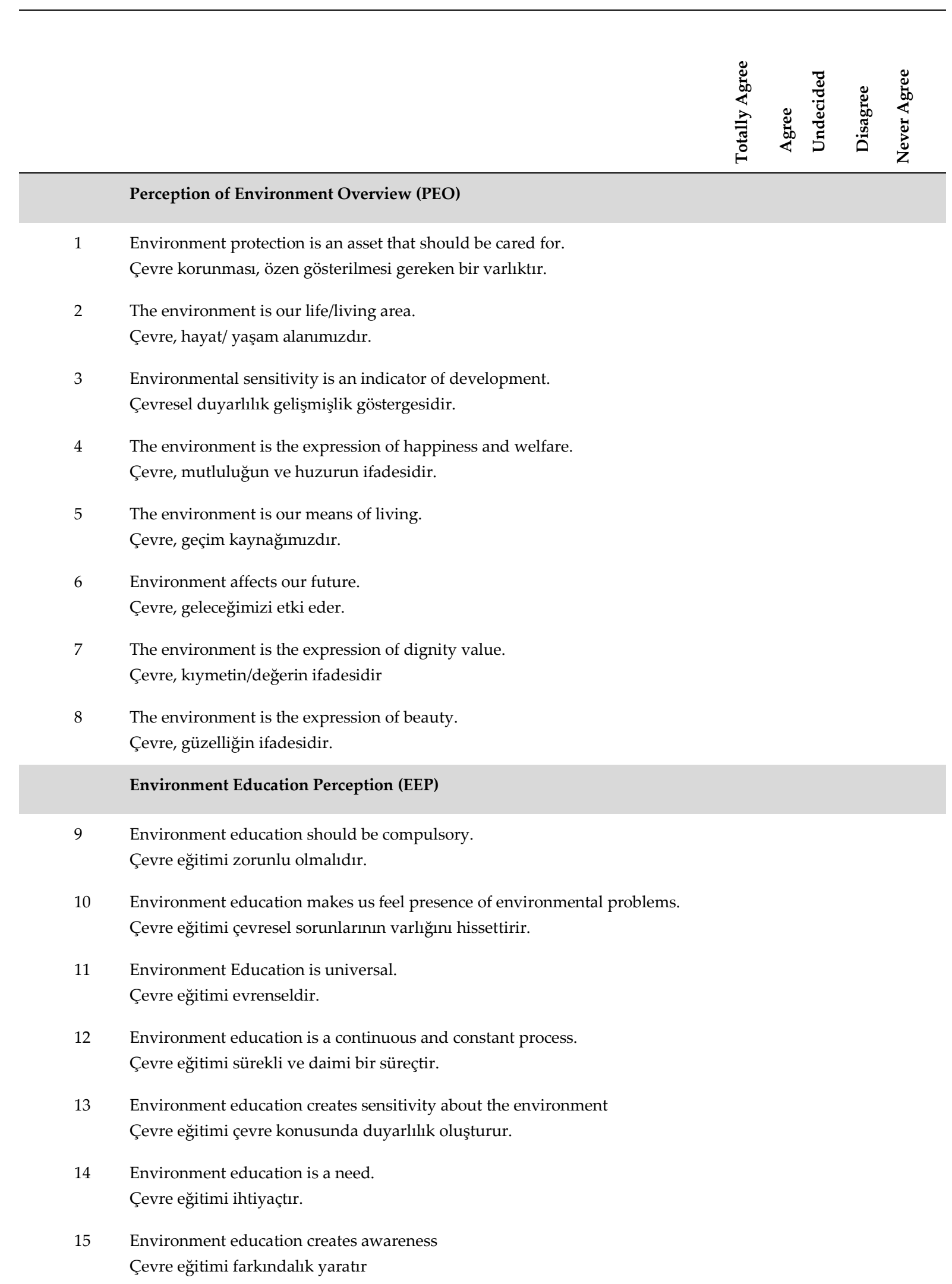

\section{Environment Protection Perception (EPP)}

16 Plants/trees should be planted to protect the environment.

Çevreyi korumak için bitki/ağaç dikilmelidir. 
17 It is a must to take precautions for environment protection.

Çevre sorunları için önlemlerin alınması gereklidir.

18 Food resources should be consumed Consciously.

Gıda kaynakları bilinçli tüketilmelidir.

19 Environment education increases economical behaviours.

Çevre eğitimi tasarruflu davranışları artırır.

\section{Environment Issues Perception (EIP)}

20 Noise is environmental pollution.

Gürültü bir çevre kirliliğ̈idir.

21 Extinction of forests is an environmental problem.

Ormanların yok olması çevre sorunudur.

22 Drought is an environmental problem.

Kuraklık bir çevre sorunudur.

23 Extreme use of natural resources leads to environment problems.

Doğal kaynakların aşırı kullanımı çevre sorunlarını oluşturur.

Environment Awareness Responsibility Perception (EARP)

24 Educators increase awareness about environmental issues. Eğitimciler çevre konularına farkındalı̆̆ı arttırır.

25 Various institutions, foundations and units can attract attention on environmental issues.

Çeşitli kurum, kuruluşlar ve birimler çevre konularına dikkat çekebilirler.

26 Legal regulations create awareness about environmental issues.

Yasal düzenlemeler çevre konularına farkındalık oluşturur.

Problems of Sensory Perception (EPSP)

27 Environmental problems create fear in me.

Çevre sorunları bende korku oluşturur.

28 Environmental problems create regret in me.

Çevre sorunları bende pişmanlıklar oluşturur.

29 Environmental problems create a feeling of guilt in me.

Çevre sorunları bende suçluluk oluşturur.

\section{Environment-Friendly Activities Perception (EFAP)}

30 Sportive activities increase environmental conscientious and awareness. Sportif faaliyetler çevresel bilinç ve farkındalığı arttırır.

31 Performing travels to nature increase environmental conscientious.

Doğa gezilerinin yapılması çevre bilincini artırır.

32 Artistic activities increase awareness about environmental issues.

Sanatsal etkinlikler, çevre konularına farkındalığı artırır. 


\section{REFERENCES}

Akgün, A., Duruk, Ü., ve Güngörmez, H. G. (2016). Ortaokul öğrencilerinin çevre eğitimi kavramına yönelik metaforları. Dicle Üniversitesi Ziya Gökalp Ĕ̆itim Fakültesi Dergisi, 28, 215-224.

AlMenhali, E. A., Khalid, K., \& Iyanna, S. (2018). Testing the psychometric properties of the Environmental Attitudes Inventory on undergraduate students in the Arab context: A test-retest approach. PloS one, 13(5), e0195250.

Arık, S ve Yılmaz, M. (2017). Fen bilimleri öğretmen adaylarının çevre sorunlarına yönelik tutumları ve çevre kirliliğine yönelik metaforik algıları. Kastamonu Eğitim Dergisi, 25(3), 1147-1164.

Arslan, A ve Zengin, R. (2016). Fen bilgisi öğretmen adaylarının küresel ısınma kavramına ilişkin algılarının metafor analizi yoluyla incelenmesi, TheJournal Of Academic Social Science Studies,44, 453-466.

Artvinli, E. \& Demir, Z.M. (2018). A study of developing an environmental attitude scale for primary school students. Journal of Education in Science, Environment and Health (JESEH), 4(1), 32-45.

Ateş, M \& Karatepe, A. (2013). Üniversite öğrencilerinin "çevre" kavramına ilişkin algılarının metaforlar yardımıyla analizi. The Journal of Academic Social Science Studies, 6(2), 1327-1348.

Atli, K. \& Uzun, N. (2016). Scale of environmental interest: The study of validity and reliability. International Journal of Innovative Research in Education, 3(4), 149-157.

Aydın, F. (2011). Üniversite öğrencilerinin çevre kavramına ilişkin metaforik algıları. Eastern Geographical Review, 16 (26), 25-44.

Aydın, F. \& Coşkun, M. (2011). The metaphoric perceptions of gifted students towards environment concept (Ankara sample-Turkey), Arch. Appl. Sci. Res, 3(2), 577-585.

Baylan, E. (2009). Doğaya ilişkin inançlar, kültür ve çevre sorunları arasındaki ilişkilerin kuramsal bağlamda irdelenmesi. Ankara Üniversitesi Çevrebilimleri Dergisi, 1(2), 67-74.

Büyüköztürk, Ş. (2005). Anket geliştirme. Türk Ĕ̆itim Bilimleri Dergisi, 3(2), 133-151.

Büyüköztürk, Ş.(2010). Sosyal bilimler için veri analizi el kitabı, Ankara: Pegem A Yayıncılık.

Can, A. (2014). SPSS ile bilimsel araştırma sürecinde nicel veri analizi. Pegem Akademi.

Cansaran, A \& Yıldırım, C. (2014). Çevre bilimi ile ilgili başlıca terimler ve kavramlar, Çevre eğitimi, (Ed. Orçun Bozkurt), Ankara: Pegem Akademi.

Christensen, B, L., Johnson, R, B. \& Turner, L, A. (2015). Araştırma yöntemleri Desen ve analiz. (Çev Ed. Ahmet Aypay) Ankara: Anı yayıncılık

Çakır, M. (2001). Canlılar bilimi, Ankara: Nobel Yayın.

Çeliker, H. D. \& Akar, A. (2015). Ortaokul öğrencilerinin doğaya ilişkin metaforları. Ahi Evran Üniversitesi Kırşehir Eğitim Fakültesi Dergisi, 16(2), 101-119.

Çopuroğlu C. (2003). İnsan-Çevre-Kültür İlişkisi Çerçevesinde Fırat Havzasında Halk Hekimliği, İstanbul Üniversitesi Sosyoloji Konferansları Dergisi, 27: 15-39.

Demir, Ö. (2017), İDKAB öğretmen adaylarının metaforik çevre algıları. International Journal of Social Sciences and Education Research,3(5), 1700-1714.

DiEnno, C. M., \& Hilton, S. C. (2005). High school students' knowledge, attitudes, and levels of enjoyment of an environmental education unit on nonnative plants. The journal of environmental education, 37(1), 1325. 
Dikmenli, Y. \& Konca, A. S. (2016). Validity and reliability study of environmental consciousness scale/Tüketici çevre bilinci algı ölçeği geçerlik ve güvenirlik çalışması. Eğitimde Kuram ve Uygulama, 12(6), 1273-1289.

Doğan, Y. (2017). Ortaokul öğrencilerinin çevre kavramına ilişkin sezgisel algıları: bir metafor analizi. Ahi Evran Üniversitesi Kırşehir Eğitim Fakültesi Dergisi (KEFAD), 18(1), 721-740.

Doğru, M. \& Sarac, E. (2013). Metaphors of primary school students relating to the concept of global warming. Educational Research and Reviews, 8(21), 2071-2082.

Erkuş, A. (2014). Psikolojide ölçme ve ölçek geliştirme. Ankara: Pegem Akademi Yayınları.

Erten, S. (2005). Okul öncesi öğretmen adaylarında çevre dostu davranışların araştırılması. Hacettepe Üniversitesi Ĕ̆itim Fakültesi Dergisi, 28(28), 91-100.

Eryılmaz, Ç., \& Kıran, Ö. (2017). Üniversite öğrencilerinin çevre algısı: Sinop Üniversitesi örneği. Akademik Sosyal Araştırmalar Dergisi, 5(61), 186-199.

Erol, G, H. (2005). Sinıf Öğretmenliği İkinci Sinıf Öğrencilerinin Çevre Ve Çevre Sorunlarına Yönelik Tutumları. Yüksek Lisans Tezi, Pamukkale Üniversitesi Fen Bilimleri Enstitüsü, Denizli.

Erol, G. H., \& Gezer, K. (2006). Sınıf Öğretmenliği Öğretmen Adaylarına Çevreye ve Çevre Sorunlarýna Yönelik Tutumları. International Journal of Environmental \& Science Education, 1(1).65-77.

Esentaş, M., Güzel, P., Özbey, S., Kılınç, Z. \& Çelebi, M. (2016). Kız öğrencilerin “doğa kampı" kavramına ilişkin metaforik algıları. International Journal of Social Science Research, 5(1), 1-16.

Gürbüz, H. \& Kışoğlu, M. (2011). Güncel çevre sorunları. Yazıcı, H. ve Arıbaş, K. (Ed.) Günümüz Dünya Sorunları. Ankara: Pegem Akademi

Gürbüz, H., \& Kışoğlu, M. (2017). Biyoloji öğretmeni adaylarının çevre okuryazarlığını artırmaya yönelik öğrenci merkezli etkinlikler hakkındaki düşünceleri. Erzincan Üniversitesi Eğitim Fakültesi Dergisi, 19(2), 74-90.

Gürbüz, H., Kışoğlu, M., Alaş, M. \& Sülün, A. (2010). Biyoloji öğretmeni adaylarının çevre okuryazarlıklarının farklı değişkenler açısından incelenmesi. e-Uluslararası Ĕ̆itim Araştırmaları Dergisi, 2(1), 1-14.

Güven, E. (2014). Fen ve teknoloji öğretmen ve öğretmen adaylarının çevre eğitimine ilişkin metaforik algıları. Eğitim ve Öğretim Araştırmaları Dergisi, 3(3), 26-37.

Güven, E. (2013). Çevre sorunlarına yönelik tutum ölçeğinin geliştirilmesi ve öğretmen adaylarının tutumlarının belirlenmesi. Gazi Üniversitesi Gazi Eğitim Fakültesi Dergisi, 33(2): 411-430.

Güven, E., \& Aydoğdu, M. (2012). Çevre sorunlarına yönelik farkındalık ölçeğinin geliştirilmesi ve öğretmen adaylarının farkındalık düzeylerinin belirlenmesi. Journal of Teacher Education and Educators, 1(2), 185202.

Goldman, D., Yavetz, B., \& Pe'er, S. (2006). Environmental literacy in teacher training in Israel: Environmental behavior of new students. The Journal of Environmental Education, 38(1), 3-22.

Jones, M. and Jones, G. (2002). Biyoloji, (Ed. L. Bikem Sözen). Birol Basın Yayın, Dağıtım ve Ticaret LTD. ŞTİ.

Kahyaoğlu, M. \& Kırıktaş, H. (2016). Ortaöğretim ve üniversite öğrencilerinin "doğa” kavramına ilişkin algılarının metafor analizi yoluyla incelenmesi. Marmara Coğrafya Dergisi, 33, 58-76.

Kahyaoğlu, M. (2015). İlköğretim öğrencilerinin doğa kavramına ilişkin algılarının metaforlar yoluyla incelenmesi. Turkish Studies International Periodical for the Languages, Literature and History of Turkish or Turkic, 10(11) , 831-846. 
Kahyaoglu, M., \& Ozgen, N. (2012). An investigation of pre-service teachers attitudes towards environmental problems in terms of several variables. Journal of Theoretical Educational Science, 5(2), 171-185.

Kaiser, F. G., Wölfing, S., \& Fuhrer, U. (1999). Environmental attitude and ecological behaviour. Journal of environmental psychology, 19(1), 1-19.

Kalayc1, Ş. (2014). SPSS uygulamalı çok değişkenli istatistik teknikleri (6. Baskı). Ankara: Asil.

Karapınar, B, Ç ve Arıbaş, K. (2017). sosyal bilgiler öğretmen adaylarının doğa eğitimi hakkında metaforik algiları, Journal of Anatolian Cultural Research,1(2), 40-66.

Karasar, N. (2005). Bilimsel araştırma yöntemleri. Ankara: Nobel Yayın Dă̆ıtım.

Kaya, M. F. (2014). Sosyal Bilgiler Öğretmen Adaylarının Çevre Sorunlarına İlişkin Algıları: Metafor Analizi. Turkish Studies-International Periodical For The Languages, Literature and History of Turkish or Turkic, 9(2),917-931.

Kaya, H., Coşkun, M. \& Aydın, F. (2010). The analysis of high school students perceptions towards "environment" concept, African Journal of Agricultural ResearchVol. 5(13), 1591-1597.

Köseoğlu, P \& Mercan, G. (2017). Üniversite öğrencilerinin hava ve hava kirliliği kavramlarına ilişkin metaforik algıları. (Ed. Özcan Demirel-Serkan Dinçer), Eğitim Bilimlerinde Yenilikler Ve Nitelik Arayışı, Ankara: Pegem Akademi. (259-268)..

Larijani, M., \& Yeshodhara, K. (2008). An empirical study of environmental attitude among higher primary school teachers of India and Iran. Journal of Human Ecology, 24(3), 195-200.

Leeming, F. C., Dwyer, W. O., \& Bracken, B. A. (1995). Children's environmental attitude and knowledge scale: Construction and validation. The Journal of Environmental Education, 26(3), 22-31.

Lloyd-Strovas, J., Moseley, C., \& Arsuffi, T. (2018). Environmental literacy of undergraduate college students: Development of the environmental literacy instrument (ELI). School Science and Mathematics, 118(3-4), 84-92.

Meral, E., Küçük, B. \& Gedik, F. (2016). Sosyal bilgiler öğretmen adaylarının çevre kavramına ilişkin metaforik algıları. Kastamonu Education Journal, 24(1), 65-78

Milfont, T. L., \& Duckitt, J. (2010). The environmental attitudes inventory: A valid and reliable measure to assess the structure of environmental attitudes. Journal of environmental psychology, 30(1), 80-94.

Nikhat, Khan, Z. (2017). Construction and Validation of Environmental Ethics Attitude Scale. IRA International Journal of Education and Multidisciplinary Studies, 7(3), 240-249.

Uyanık, B. (2012). İlköğretim ikinci kademe öğrencilerinin küresel çevre sorunlarına yönelik metaforları. Yüksek Lisans Tezi, Gaziosmanpaşa Üniversitesi Sosyal Bilimler Enstitüsü, Tokat.

Pelletier, L. G., Tuson, K. M., Green-Demers, I., Noels, K., \& Beaton, A. M. (1998). Why are you doing things for the environment? The motivation toward the environment scale (mtes) 1. Journal of Applied Social Psychology, 28(5), 437-468.

Ponmozhi, D. \& Krishnakumari, S. (2017). Environmental Attitude of School Students, IOSR Journal of Humanities and Social Science (IOSR-JHSS) 22, (7), 01-04.

Sadik, F., Çakan, H., \& Artut, K. (2011). Analysis of the environmental problems pictures of children from different socio-economical level. Ilkogretim Online, 10(3). 1066-1080.

Saraç, E., \& Kan, A. (2015). Öğretmen adayları için çevre konularına yönelik tutum ölçeği geliştirme geçerlik ve güvenirlik çalışması. Journal of Research in Education and Teaching, 4(2), 142-150. 
Seçer, İ. (2017). SPSS ve LISREL ile Pratik Veri Analizi Analiz ve Raporlaştırma. Ankara: Anı Yayıncılık.

Simon, E, J. (2015). Ekoloji (Tavşanoğlu, Ç. Çev.), Biyoloji: öz; (F. Eyidoğan Çev. Ed.), Ankara: Nobel Yayın.

Sontay, G., Gökdere, M., \& Usta, E. (2014). The Study of Scale Developing Related To The Environmental Literacy Component on the Secondary School Level. Necatibey Faculty of Education Electronic Journal of Science and Mathematics Education, 9(1), 49-80.

Soydan, S. B., \& Samur, A. Ö. (2017). Validity and reliability study of environmental awareness and attitude scale for preschool children. Electronic Journal of Environmental Education, 7(1), 78-96.

Sönmez, E., \& Yerlikaya, Z. (2017). Ortaokul Öğrencilerinin Çevresel Bilgi Düzeyleri ve Çevreye Yönelik Tutumları Üzerine Bir Alan Araştırması: Kastamonu İli Örneği. Kastamonu Eğitim Dergisi, 25(3), 12391249.

Starr, C. \& Taggart, R. (1997). Genel Biyoloji II. (Çev. İsmet Hasanekoğlu). Atatürk Üniversitesi Yayınları No.900, K.K. Eğitim Fakültesi Yayınları No.113, Ders Kitapları Serisi No.57. Erzurum.

Szczytko, R., Stevenson, K., Peterson, M. N., Nietfeld, J., \& Strnad, R. L. (2018). Development and validation of the environmental literacy instrument for adolescents. Environmental Education Research, 1-18.

Sülün, Y. (2002). Çevre kirliliğini önlemede eğitimin rolü. Muğla Üniversitesi SBE Dergisi, 8,1-9.

Talas, M. \& Karataş, A. (2012). Çevre bilincinin geliştirilmesinde topluma hizmet uygulamaları dersinin önemi: Niğde üniversitesi sınıf öğretmenliği programı örneği, Zeitschrift für die Welt der Türken Journal of World of Turks, 4(1), 107-125.

Tezbaşaran, A. A. (2008). Likert tipi ölçek hazırlama kılavuzu (e-kitap). Erişim: tarihi: 10.02.2019 http://www. academia.edu/1288035/Likert_Tipi_Ölçek_Hazırlama_Kılavuzu.

Odum, E. P. (1959). Fundamentals of ecology. WB Saunders company.

Ok, G., \& Başlar, S. (2015). İnsan ve Çevre Ünitesine Yönelik Bir Çevre Bilgisi Testi (Çbt) Geliştirme ve Geçerlik-Güvenilirlik Çalışması. Batı Anadolu Ĕ̆itim Bilimleri Dergisi, 6(11), 137-155.

Ötün, Y., Artun, H., Temur, A., \& Tozlu, İ. Ortaokul öğrencilerine yönelik çevre eğitimi kavramları farkındalık ölçeği: geçerlik ve güvenirlik çalışması. Yüzüncü Yıl Üniversitesi Eğitim Fakültesi Dergisi, 14(1), 511-528.

Özata Yücel, E., \& Özkan, M. (2014). Fen bilimleri öğretmen adaylarının çevre algılarının kelime ilişkilendirme aracilı̆̆ıyla belirlenmesi. E-international journal of educational research, 5(4), 41-56.

Özerkmen, N. (2017). İnsan merkezli çevre anlayışından doğa merkezli çevre anlayışına. Ankara Üniversitesi Dil ve Tarih-Coğrafya Fakültesi Dergisi, 42(1-2). 167-185

Özdemir, A., Aydın, N., \& Akar Vural, R. (2009). Çevre eğitimi öz-yeterlik algısı üzerine bir ölçek geliştirme çalışması. Dokuz Eylül Üniversitesi Buca Ĕ̆itim Fakültesi Dergisi 26, 1-8.

Özer, N., \& Keleş, Ö. (2016). Çevre etiği farkındalık ölçeği geliştirme çalışması [environmental ethics awareness scale development study]. Fen Bilimleri Öğretimi Dergisi, 4(1), 47-64.

Özlü, G., Keskin, M. Ö., \& Gül, A. (2013). Çevre Eğitimi Öz-Yeterlik Ölçeği Geliştirilmesi: Geçerlik ve Güvenirlik Çalışması. Gazi University Journal of Gazi Educational Faculty (GUJGEF), 33(2), 393-410.

Özmen, H., \& Özdemir, S. (2016). Fen ve teknoloji öğretmen adaylarının çevre eğitimine yönelik düşüncelerinin tespiti. Kastamonu Education Journal, 24(4). 1691-1712

Özsevgeç, T., Artun, H., \& Özsevgeç, L. C. (2010). Development of environmental literacy scale for prospective teachers. Educational Research, 1(8), 239-245. 
Yazıcı, Ö. (2013). Coğrafya öğretmenlerinin çevre kavramına ilişkin algıları: bir metafor analizi çalışması, The Journal Of Academic Social Science Studies, 6(5), 811-828.

Ugulu, I., Sahin, M., \& Baslar, S. (2013). High school students environmental attitude: Scale development and validation. International Journal of Educational Sciences, 5(4), 415-424.

Uzun, N., Gilbertson, K. L., Keles, O., \& Ratinen, I. (2019). Environmental Attitude Scale for Secondary School, High School and Undergraduate Students: Validity and Reliability Study. Journal of Education in Science, Environment and Health, 5(1), 79-90.

Uzun, N. \& Sağlam, N. (2005). Sosyo-ekonomik durumun çevre bilinci ve çevre akademik başarısı üzerine etkisi. Hacettepe Üniversitesi Ĕ̆itim Fakültesi Dergisi, 29(29), 194-202.

Uzun, N., \& Sağlam, N. (2006). Orta öğretim öğrencileri için çevresel tutum ölçeği geliştirme ve geçerliliği. Hacettepe Üniversitesi Ĕ̆itim Fakültesi Dergisi, 30(30), 240-250.

Uzunöz, A. (2011). Reliability and validity towards environment attitude scale for secondary school students. Educational Research and Reviews, 6(16), 893-901.

Yalçınkaya, E. (2013). İlköğretim 8. sınıf öğrencilerine göre çevre sorunları: nitel bir çalışma. Marmara Coğrafya Dergisi Sayı: 27,. 416-439

Yeşilyurt, S., Gül, Ş \& Demir, Y. (2013). Biyoloji öğretmen adaylarının çevre bilinci ve çevresel duyarlılığı: ölçek geliştirme çalışması. Mehmet Akif Ersoy Üniversitesi Eğitim Fakültesi Dergisi, 1(25). 38 - 54

Yılmaz, O., Bedur, S. \& Uysal, R. (2016). Çocukların çevreye ilişkin görüşleri: salda gölü örneği. Hasan Âli Yücel Eğitim Fakültesi Dergisi, 13(2), 59-72.

Yücel, M., Altunkasa, F., Güçray, S., Uslu, C., Say, N. P., \& Say, N. P. (2006). Adana'da çevre duyarlılığ1 düzeyinin ve geliştirme olanaklarının araştııılması. Akdeniz Üniversitesi Ziraat Fakültesi Dergisi, 19(2), 217-228. 